Araştırma Makalesi- Research Article

\title{
Akarsu Köprülerinin HEC-RAS Programı ile Hidrolik Analizi: Fidanlık Köprüsü Örneği
}

\author{
Nuri Y1lmaz ${ }^{*}$, Hasan Bozkurt ${ }^{2}$, Ylldırım Bayazıt $^{3}$ \\ Geliş / Received: $27 / 04 / 2020$ \\ Revize / Revised: 24/06/2020 \\ Kabul / Accepted: 02/07/2020
}

ÖZ

Dünyada hızla artan insan nüfusu sonucu oluşan plansız kentleşme ve iklim değişiklikleri sebebiyle meteorolojik kaynaklı doğal afet olayları oldukça artmıştır. Bu doğal afetlerin en önemlilerinden biri taşkınlardır. Taşkınlar, can ve mal kayıplarına neden olarak sosyal ve ekonomik olarak zararlar vermektedirler. Meydana gelen taşkınlarda akarsu üzerinde bulunan su yapılarının özellikleri oldukça önem arz etmektedir. Taşkınların yıkıcı etkisini artıran en önemli su yapılarından bir tanesi iyi tasarlanmamış olan akarsu köprüleridir. Akarsu üzerinde bulunan ve hidrolik açıdan iyi tasarlanmamış bir köprü taşkının şiddetini daha da artırmakta ve yıkılma tehlikesiyle karşı karşıya kalarak insanların can ve mal güvenliğini tehlikeye atmaktadır. Geçmişte akarsular üzerine yapılan köprülerin statik açıdan uygunlukları test edilirken günümüzde hidrolik açıdan güvenilirliği de test edilerek daha güvenli köprüler yapılmaktadır. Bu çalışmada Eskişehir Orman Fidanlık bölgesine yapılmış olan bir köprünün 50 yıllık ve 100 yıllık taşkın debilerine karşı güvenilirliği ArcGIS ve HEC-GeoRAS ile modellenerek HEC-RAS ile test edilerek yorumlanmıştır.

Anahtar Kelimeler- Taşkın, Köprüler, HEC-RAS, Doğal Afet

1*Sorumlu yazar iletişim: nuriyilmaz@dsi.gov.tr (https://orcid.org/0000-0002-2226-5662)

DSİ 31. Şube Müdürlüğü, DSI III. Bölge Müdürlüğü, Odunpazarı, Eskişehir

2İletişim: hasan.bozkurt@bilecik.edu.tr (https://orcid.org/0000-0001-7539-8285)

Inșaat Müh. Bölümü, Bilecik Șeyh Edebali Üniversitesi, Gülümbe Kampüsü, Merkez, Bilecik

3İletişim: yildirim.bayazit@bilecik.edu.tr (https://orcid.org/0000-0002-8699-4741)

İş̧aat Müh. Bölümü, Bilecik Şeyh Edebali Üniversitesi, Gülümbe Kampüsü, Merkez, Bilecik 


\title{
Hydraulic Analysis of River Bridges with HEC-RAS Software: Example of Fidanlık Bridge
}

\begin{abstract}
Due to the unplanned urbanization and climate changes caused by the rapidly increasing human population in the world, natural disasters caused by meteorological conditions have increased considerably. One of the most important of these natural disasters is floods. Floods cause social and economic damage by causing loss of life and property. In the floods that occur, the features of the water structures on the river are very important. One of the most important water structures that increase the destructive effect of floods are the river bridges that are not well designed. A bridge on the river, which is not hydraulically designed well, increases the severity of flooding and endangers the safety of people and property by facing collapse. While the static suitability of the bridges built on rivers in the past was tested, nowadays hydraulic reliability is tested and safer bridges are built. In this study, the reliability of a bridge constructed in the Eskişehir Forest Fidanlı region against 50 years and 100 years of flood flows was modeled with ArcGIS and HEC-GeoRAS and tested and interpreted with HEC-RAS.
\end{abstract}




\section{GíRiș}

Akarsu köprüleri, insanların uygarlığı boyunca geçmişten günümüze ulaşım ağlarının en önemli yapılarındandır. Köprülere insan, taşıt, deprem, rüzgâr, taşkın anındaki hidrolik kuvvet ve akarsuda sürüklenen malzemenin etki etmesi gibi birçok farklı yük parametresi etki etmektedir. Bu etkilerin karşılanarak insanların can ve mal güvenliğinin sağlanabilmesi için köprülerin statik ve hidrolik açıdan iyi bir şekilde tasarlanması gerekmektedir. Köprü tasarımına ait yük değerleri, köprü üzerine etki eden kuvvetler sonucu aş1lırsa köprü hasar görebilir veya yıkılabilir. Akarsu köprülerinde meydana gelen hasar ve yıkılmaların nedenleri incelendiğinde ise ilk sırada hidrolik etkenler gelmektedir. Taşkın anında hidrolik açıdan iyi tasarlanmamış bir akarsu köprüsü ayaklarında veya tabliyesinde meydana gelen hasarlar neticesinde zarar görmekte veya yıkılmaktadır [1]. Köprülerin yapıldığı yerdeki akarsuyun hidrolojik özellikleri, gelebilecek taşkın debileri, akarsuyun taşıdığı malzeme miktarı ve bölgenin topoğrafik özellikleri de iyi bir şekilde irdelenerek güvenli köprü tasarımları yapılmalıdır. Yapısal olarak iyi bir şekilde analiz edilmiş bir köprüde, köprünün taşkın anında gelebilecek debilerdeki davranışının da bilinmesi köprü tasarımını tamamlayan kriterlerindendir [2].

HEC-RAS programı ile akarsu ve havzaların taşkın risk analizleri bilgisayar ortamında yapılarak çıkacak problemler önceden analiz edilebilmektedir. Bülbül ve Demirel [3], Ovacuma bölgesinde Ova Çayında bulunan Akkışla köprüsünde taşkın sırasında oluşabilecek kabarmaları HEC-RAS programı ile inceleyerek alınacak önlemleri belirtmiş̧lerdir. Yapılan analizler sonucunda 500 yıllık feyezan debisinin köprüyü aştı̆ğ görülmüş̧ür. Elde edilen taşkın risk haritaları ile alınabilecek önlemler analiz edilmiş ve en sağlıklı yöntemin akarsu dere yatağında yarma işlemini yaparak yatağı genişletmek olduğu karanına varılmıştır. Proje mühendisinin havza çalışmalarında ve su yapısı tasarımlarında bulunurken bölgenin taşkın risk haritasını oluşturarak çalışmasının ileride çıkabilecek aksaklıkları azalttığı, ekonomik sonuçlar doğurduğu görülmüştür. Bunun sonucunda insanların can ve mal güvenliği için daha sağlıklı tasarımlar yapılabileceği sonucuna varılmıştır. Doğu ve Yıldız [4], Kırıkkale ili içerisinden geçen Kızılırmak nehrinin yan kolu olan Çoruhözü deresinin şehir içerisinden geçen ve DSİ tarafından ıslah edilen $8 \mathrm{~km}$.' lik beton taşkın kanalını incelemişlerdir. $\mathrm{Bu}$ kanalın 500 ve 100 yıllık taşkın debilerindeki güvenilirliği HEC-RAS programı ile test edilmiş ve yorumlanmıştır. Yeni tarihli yapılan analizler sonucunda kanal kesitinin taşkın debilerini karşılama da yeterli olmadığı görülmüştür. Su yapıları tasarım ve uygulama aşamasında yeni tarihli yağış verilerin elde edilerek tasarım yapılmasının öneminden bahsedilmiştir. Ayrıca mevcut su yapılarııın güncel yağış verilerindeki durumunun analizinin önemi belirtilmiştir. Efe ve Önen [5], Batman Çayı üzerinde bulunan Yeni Malabadi Köprüsü ve Diyarbakır - Batman Karayolunda ulaşımı sağlayan köprüler arasındaki kesimlere ait taşkın analizlerini HEC-RAS programı ile yaparak çözüm önerileri sunmuşlardır. Batman Çayının bu kesiminde yapılan analizler sonucu Çayın bu kesiminde eğimin az, menderesler yaparak akması ve akarsu yatağının geniş olmasına rağmen akarsu kesitinin taşkın debisini karşılamakta yetersiz kaldığı görülmüştür. Bölgenin taşkın tehlikesi altında olduğu derenin ıslah edilmesinin gerekliliği belirtilerek bölgeye yapılacak barajın biran evvel bitirilmesi gerektiği bu sayede tehlikenin ortadan kalkacağı konuları belirtilmiştir. Ercan ve ark.[6], Kahramanmaraş ilinin, On iki Şubat ilçe merkezinde bulunan mahalleleri taşkın riskinden korumak için yapılan kuşaklama kanalı projesinin uygunluğunu HEC-RAS programı ile analiz ederek Mockus ve rasyonel metot ile uyumluluklarını test ederek yorumlamışlardır. On iki Şubat ilçesinde bulunan Domuz deresinde yaşanan taşkınlar sonucu dere çevresindeki mahallelerde taşkınlar yaşanmıştır. Bunun sonucunda dere üzerine DSİ tarafından kuşaklama kanalları yapılmış ve bölgenin taşkın riski azaltılmak istenmiştir. Dere üzerine yapılan kuşaklama kanallarının taşkın risk analizleri ayrıca HEC-RAS ile test edilmiş ve sonuçların birbirine çok yakın çıktığı görülmüştür. Karaca ve ark.[7], Sivas'ın Suşehri ve Koyulhisar ilçelerinden geçen Kelkit Çayı'nın bu kısımlardaki taşkın risk haritaları oluşturularak, taşkının oluşturacağı etkiler analiz edilmiştir. Yapılan analiz sonucu Kelkit çayının bu bölgesinde bulunan şehirlerarası otoyollar ve verimli tarım arazilerin taşkın riski altında olduğu görülmüsş, alınabilecek önlemler ve analizlerin daha sağlıklı yapılabilmesi için önerilerde bulunulmuştur. Özdemir [8], Balıkesir Havran Çayında Oldukça fazla taşkın meydana geldiği bu nedenle çay üzerine taşkını önlemek için baraj ve birçok su yapısı yapıldığı, yapılan bu yapıların uygunluğu ve bölgenin taşkın risk haritalarının HEC-RAS programı ile çıkarılarak yorumlanması amacıyla bir çalışma yapmıştır. Yapılan analizler sonucu Havran Çayı üzerine yapılan su yapılarının Havran ilçesini korusa dahi bölge halkının geçim kaynağı olan tarım arazilerinin tehlikede olduğu görülmüştür. Bu duruma neden olarak Havran Çayına yapılan barajdan sonra katılan yan derelerin etkisinin oldukça fazla olduğu görülmüş ve alınması gereken önlemler belirtilmiştir. Ayrıca HEC-RAS ve HEC-GeoRAS ile yapılan akarsu analizlerinin öneminin görüldüğü vurgulanmıştır. Seçilir [9], tarafından akarsu köprü ayaklarında oluşabilecek kabarmaların hesabında Biery, 
Delleur ve Polinomial yaklaşımları laboratuvar ortamında bulunan sonuçlar analiz edilerek yorumlanmıştır. Yapılan deneyler sonucunda akarsu köprülerinde maksimum su kabarma yüksekliği için eliptik şeklinde açıklığı bulunan akarsu köprülerinde Biery ve Delleur yöntemlerinin daha iyi sonuçlar verdiği görülmüştür. Dikdörtgen açıklıklı köprülerde Polinomial yönteminin daha iyi sonuçlar verdiği, dairesel açıklıklı köprülerde de her iki yönteminde benzer sonuçlar verdiği görülmüştür. Taş ve ark.[10], Afyon'da bulunan Akar çayın alt havzasında farklı dönüş aralıklarında oluşabilecek taşkın debilerindeki su seviyeleri ve su altında kalma tehlikesi yaşayacak yerlerin HEC-RAS programı kullanılarak analiz edilmesi amaçlanmıştır. Çalışma sonucunda taşkın riskine maruz kalacak alanlar belirlenerek bu alanlarda alınacak önlemler ve tavsiyeler belirtilmiştir. Akarsuyun çevresinin yeşil alan ve park olarak tasarlanması, taşkın riski altındaki evlerde taşkın riskine karşı önlemler alınması ve akarsuyun yan kollarının da ayrıca analiz edilmesi önerilen konulardır. Üyüklüoğlu ve ark.[11], Manavgat ilçesi, Ilıca Deresinin taşkın risk analizi yapılarak bölgede bulunan tarım arazileri, yerleşim alanları ve su yapılarının güvenliği HEC-RAS programı ile test edilerek yorumlanmıştır. Ilıca deresi üzerinde bulunan su yapılarından bazılarının $Q_{500}$ taşkın debisinde yetersiz kaldığı görülmüştür. Bölgede bulunan turistik oteller ve tarım arazileri düşünülerek akarsu kesitinde alınacak önlemler önerilmiştir. Ayrıca akarsuyun denize döküldüğü noktada da önlemler alınması gerektiği, akarsuyun konumu sebebiyle turistik bir noktada olması sebebiyle yapılacak tasarımların bu durum da dikkate alınarak yapılması gerektiği önerilmiştir.

Bu çalışmada Eskişehir Orman Fidanlık bölgesinde, Porsuk Çayı üzerine DSİ tarafından yapılmış olan Fidanlık Köprüsünün yapısal ve hidrolik açıdan güvenliğini, yukarıda bahsedilen sebeplere göre ve yapılmış olan benzer akademik çalışmaları da dikkate alarak yapılmış olan tasarımının uygunluğunun ve köprünün güvenliğinin test edilmesi ve değerlendirilmesi hedeflenmiştir. Bu hedef doğrultusunda yapımı tamamlanan köprünün sadece yapısal olarak güvenilirliği değil, aynı zamanda hidrolik etkenler açısından da güvenilirliği test edilmiş olacaktır. Çalışmada akarsu köprüsünün 50 ve 100 yıllık taşkın debilerindeki davranışı incelenerek, köprünün hidrolik açıdan güvenilirliği ArcGIS ve HEC-GeoRAS programı ile modellenmiş ve HEC-RAS paket programı yardımıyla analiz edilerek yorumlanmıştır.

\section{II. ÇALIŞMA ALANI}

Şekil 1'de Fidanlık Köprüsünün yeri ve arazinin uydu görüntüsü verilmiştir. Uydu görüntüsünde görüldüğü gibi köprünün yapılacağı yerin karşısında bulunan fidanlık alanına ulaşım akarsu üzerinde köprü bulunmadığı için Kütahya yolu üzerinden yaklaşık 3,5 - $4 \mathrm{~km}$. daha fazla yol gidilmesi gerekmektedir. Ayrıca araziler arasında iş ve tarım makinesi geçişleri gerektiği için Kütahya yolunun kullanılarak ulaşımın sağlanması tehlikeli olmaktadır. Bu nedenle köprünün yapılması planlanmıştır. DSİ 3. Bölge Müdürlüğü, Sakarya havzası master planları kapsamında Porsuk alt havzası taşkın etüt master plan raporu hazırlamıştır. Bu raporda köprünün memba kısmında kalan havzaların taşkın büyüklükleri DSİ Sentetik metoda göre hesaplanarak köprünün yapılacağ1 yere süperpoze edilmiştir. Buna göre köprünün konumlandırıldığı yerdeki taşkın debileri $\mathrm{Q}_{50}=139,58$ $\mathrm{m}^{3} / \mathrm{s}, \mathrm{Q}_{100}=211,40 \mathrm{~m}^{3} / \mathrm{s}$ olduğu belirlenmiştir.

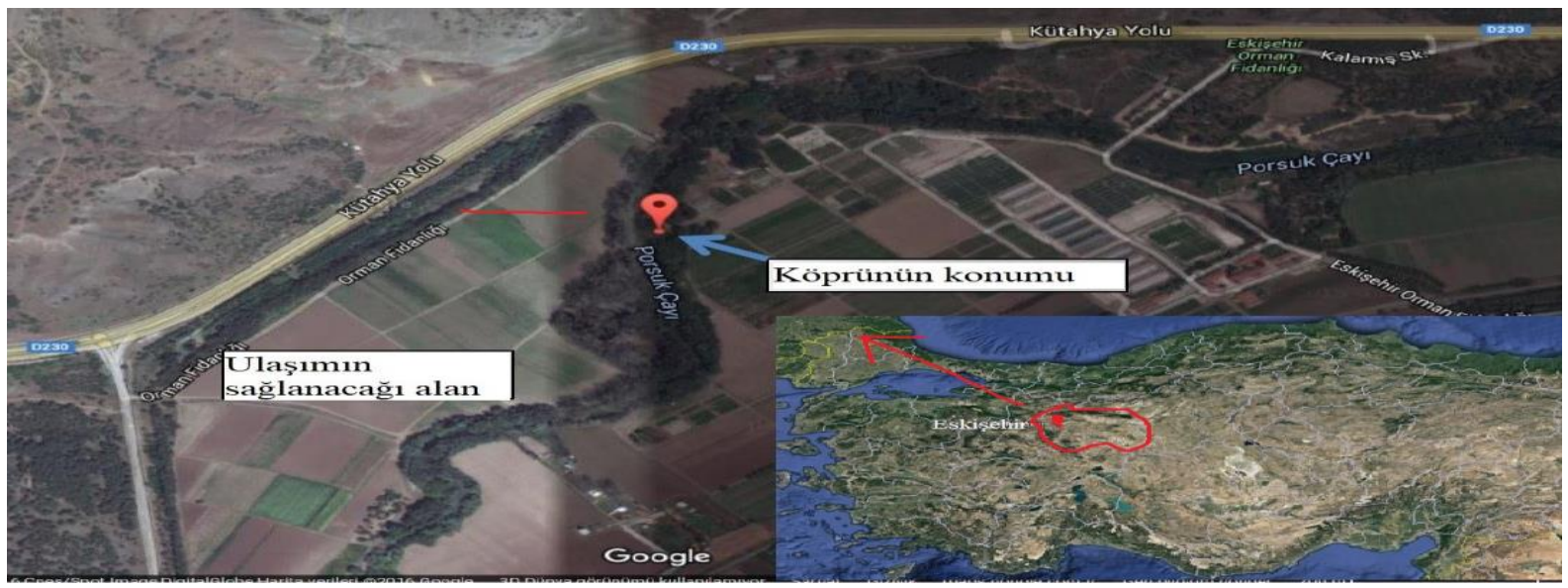

Şekil 1. Köprü yerine ait uydu görüntüsü 


\begin{tabular}{|c|c|c|}
\hline & $\begin{array}{l}\text { BŞEÜ Fen Bilimleri Dergisi } \\
7(2), 896-910,2020\end{array}$ & $\begin{array}{r}\text { BSEU Journal of Science } \\
\text { DOI: } 10.35193 / \text { bseufbd.715657 }\end{array}$ \\
\hline & & 58-7575 (http://dergipark.gov.tr/bseufbd) \\
\hline
\end{tabular}

Köprünün projesinde tabliye yüksekliği $\mathrm{Q}_{100}$ su seviyesine, 1,5 metre de hava payı eklenmesi ile tasarlanmıştır. Arazi çalışmalarında akarsuyun her iki sahilinde de köprü ayaklarının konumlandırılacağı noktada sağlam zemin bulunamazsa 25 metre, sağlam zemine ulaşılır ise 5 metre sondaj yapımı uygun görülmüştür. Arazide harita alımları yapılarak köprünün tasarımı ve konumu belirlenerek en uygun yere konulmuştur. Köprünün tek açıklıkla geçilerek orta ayak bulunmaması kararına varılarak yapılmıştır. Köprünün mansabından bir görüntü Şekil 2'de gösterilmiştir.

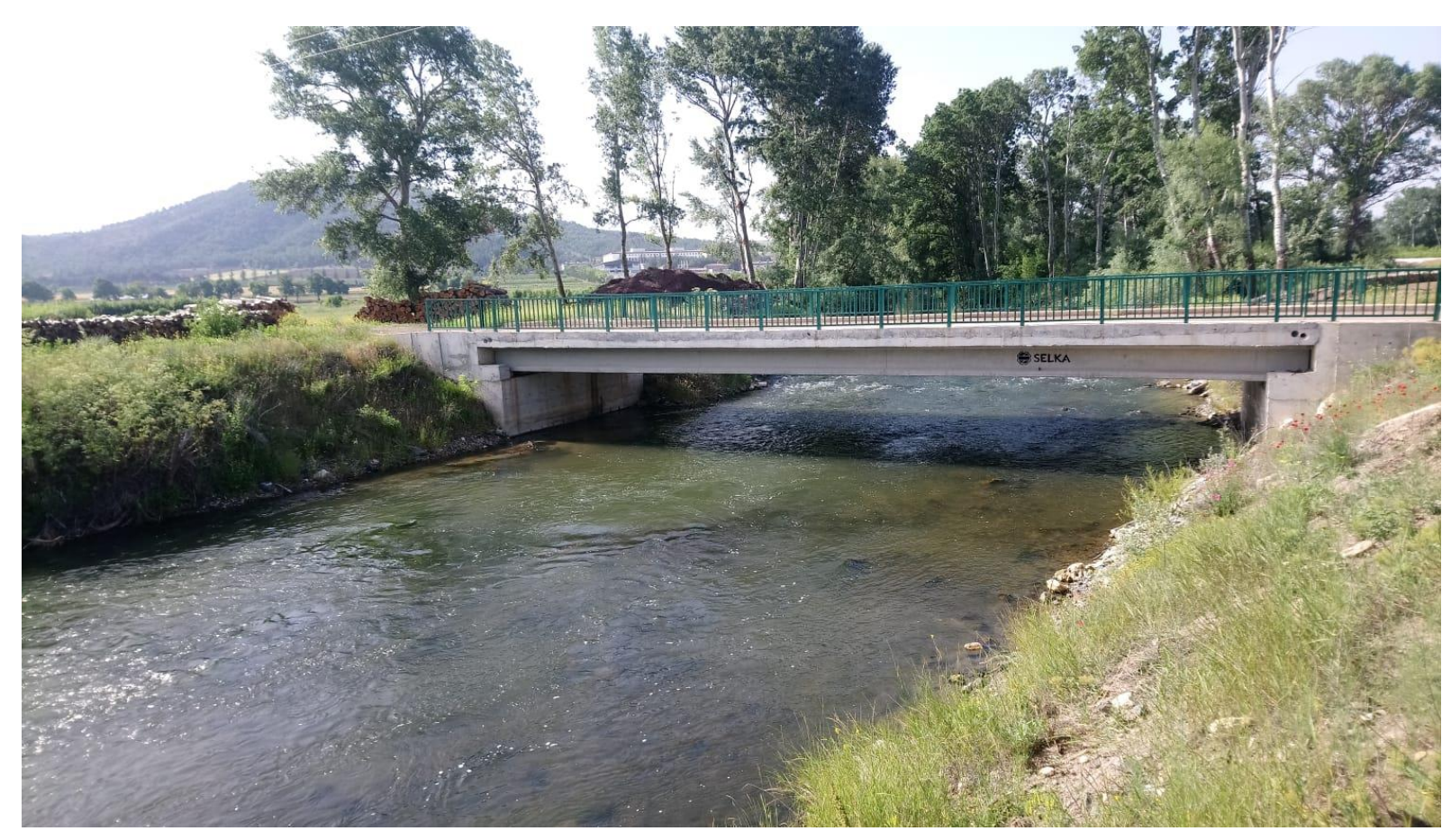

Şekil 2. Köprünün arazideki görüntüsü

\section{YÖNTEM}

Bu çalışmada 1/25.000 ölçekli topoğrafik yükseklik haritaları (Harita Genel Müdürlüğü ve DSİ 3. Bölge Müdürlüğü) kullanılarak sayısal yükseklik modeli (DEM) oluşturulmuştur. Daha sonra köprünün bulunduğu bölgeye ait TIN (TriangulatedIrregular Network)arazi modeli ArcGIS programı ile oluşturulmuştur. Oluşturulan TINmodeli üzerinde geometrik veriler (akarsu, akarsu kıyı çizgisi, akış yolları, en kesitler, köprünün yeri ) HECGeoRAS yardımıyla oluşturulmuştur. Daha sonra TIN üzerine akarsuya ait işlenmiş olan geometrik veriler HECRAS programına aktarılarak burada akarsu ve köprüye ait sayısal veriler girilerek köprünün taşkın anındaki analizi yapılmıştır. Analiz yapımına ait işlem basamakları Şekil 3'de ayrıntılı olarak gösterilmiş ve aşağıda sırasıyla anlatılmıştır. 


\begin{tabular}{|c|c|c|}
\hline & $\begin{array}{l}\text { BŞEÜ Fen Bilimleri Dergisi } \\
7(2), 896-910,2020\end{array}$ & $\begin{array}{r}\text { BSEU Journal of Science } \\
\text { DOI: } 10.35193 / \text { bseufbd. } 715657\end{array}$ \\
\hline & & 58-7575 (http://dergipark.gov.tr/bseufbd) \\
\hline
\end{tabular}

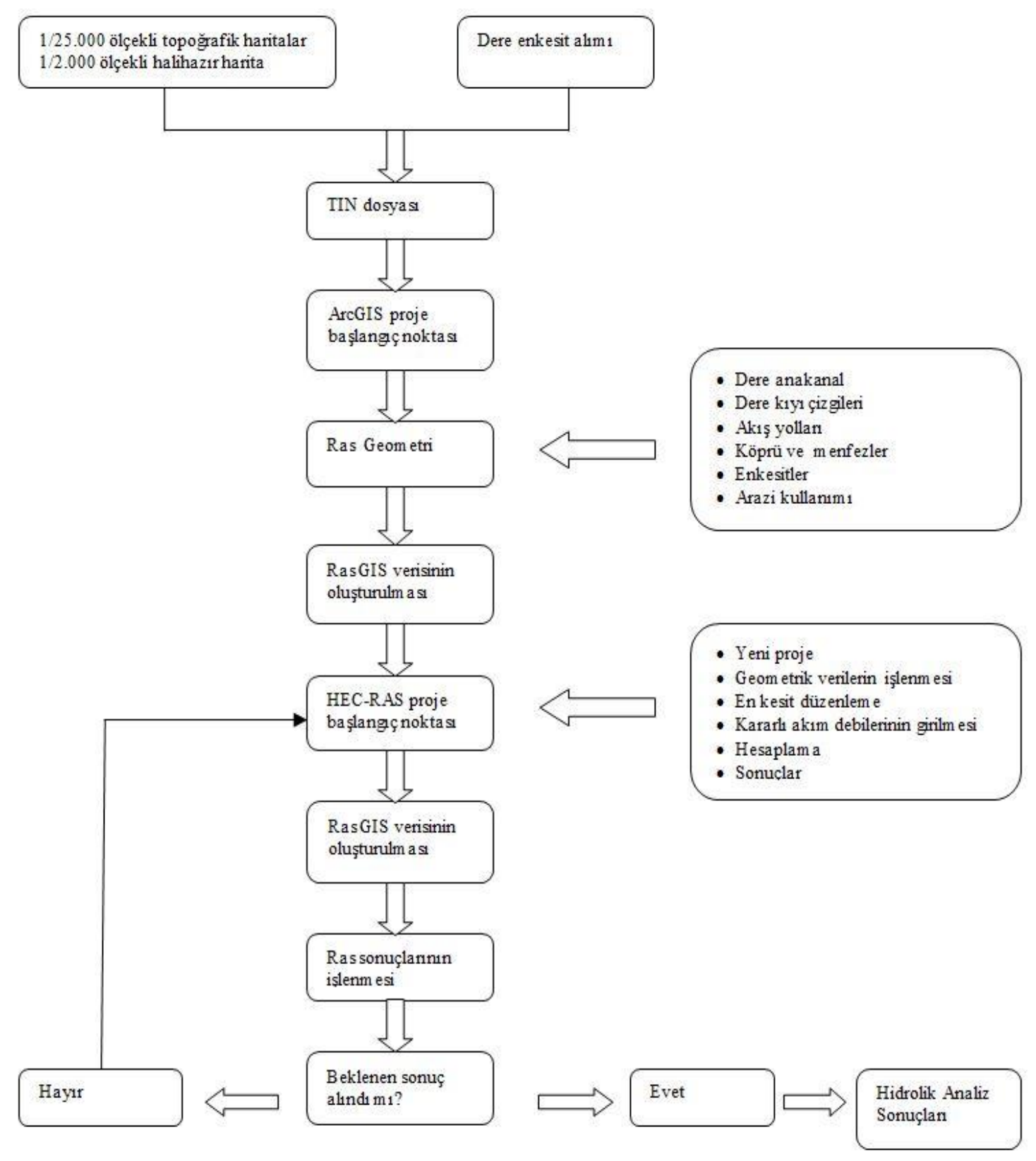

Şekil 3.Çalışmada uygulanan yöntemin iş akış şeması

\section{A. Geometrik Verilerin İşlenmesi}

Akarsular üzerinde bulunan su yapıları ve akarsuya ait hidrolik modellemeler yapabilmek için akarsuya ait geometrik verilerinin girilmesi gereklidir.

Çalışmada köprünün bulunduğu bölgeye ait TIN haritasını oluşturduktan sonra Porsuk Çayı üzerine akış güzergâhı çizerek, akarsu sağ ve sol sahilindeki taşkın alanlarını ve akarsuya ait kıyı sınırları çizilmiştir. Köprünün memba ve mansabında toplam 20 adet kesit çizgisi oluşturulmuştur. Bu kesitlerin 10 tanesi köprünün memba tarafından, 10 tanesi ise mansap tarafından alınmıştır. Çalışmada incelenen akarsu güzergâhının kısa olması en kesit sayısının 20 adetle analiz için yeterli kesitleri sağlayacağı düşünülerek oluşturulmuştur. Ayrıca güzergah boyunca kesit sayısının arttırılması kesit çizgileri arasındaki mesafeyi kısaltacağından menderesli 


\begin{tabular}{|c|c|c|}
\hline & $\begin{array}{l}\text { BŞEÜ Fen Bilimleri Dergisi } \\
7(2), 896-910,2020\end{array}$ & $\begin{array}{r}\text { BSEU Journal of Science } \\
\text { DOI: } 10.35193 / \text { bseufbd.715657 }\end{array}$ \\
\hline & & 58-7575 (http://dergipark.gov.tr/bseufbd) \\
\hline
\end{tabular}

yapıdaki akarsuyu güzergahında kesitler arasında çakışma problemi yaratabileceği düşünülmüştür. Kesit sayısının gerektiğinden fazla olması durumu çakışma sorunları yaratabilirken gerektiğinden az olması durumunda ise akarsu kesiti yeteri kadar tanımlanamayarak su yüzeyi profillerinin oluşmasında hatalı değerler çıkarabilmektedir. En kesit çizimi yapılırken çizimlerin membadan mansaba doğru olmasına dikkat edilmiştir. Şekil 4'de HEC-GeoRAS yardımıyla oluşturulmuş olan 10'ar adet en kesit, akış güzergâhı ve kıyı çizgileri gösterilmiştir. En kesitler alınırken akarsuyu dik bir şekilde kesmesine, soldan sağa doğru çizilmesine ve çizilen akarsu kıyı, taşkın çizgilerinin hepsini birden içerisine alacak şekilde çizilmesine dikkat edilmiştir. Oluşturulan geometrik veriler HEC-GeoRAS ile TIN haritasının üzerine işlenerek Export edilerek HEC-RAS'a verilerin aktarılacağı sdf uzantılı bir veri dosyası oluşturulmuştur.

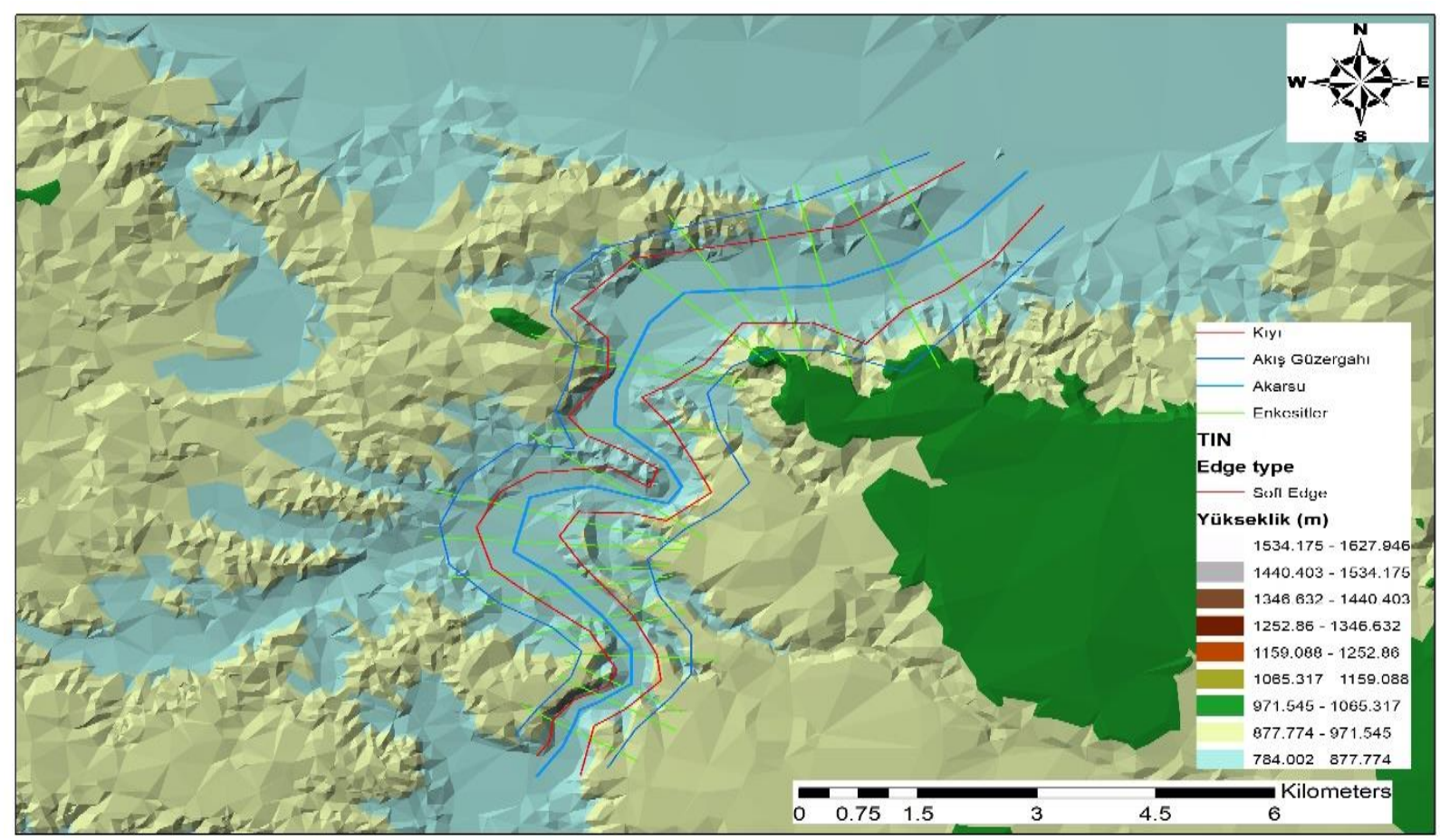

Şekil 4. HEC-GeoRAS ile çizilen enkesitler

\section{B. Sayısal Verilerin Işslenmesi}

HEC-RAS programı, ArcGIS programıyla beraber çalışarak uydu görüntülerini işleyerek çalışabilen grafik tabanlı ve kullanımı rahat olan bir yazılımdır. Ayrıca HEC-RAS tek boyutlu, sürekli akımlara ait su yüzeylerinin hesaplandığı ve süreksiz akımlara ait modellemelerin yapılabildiği, veri saklama ve yönetim kapasitesine sahip bir hidrolik yazılım programıdır[12].

HEC-RAS programı içerisinde bazı su yapılarına ve köprü tasarımına ait sayısal verilerin girilebilmesi için ayrıca bir sekme bulunmaktadır. Programın içerisine Arc-GIS ve HEC-GeoRAS ile oluşturularak kaydedilmiş olan sdf uzantılı dosya çağrılarak köprünün ve bulunduğu noktanın memba ve mansabına ait sayısal veriler Şekil 5'te gösterildiği gibi programa girilmiştir. Burada Upstream (memba) tarafı, Downstream (mansap) ise tarafına ait köprünün konum verileridir. Böylelikle oluşturulan TINverisi içerisine akarsu köprüsünün sayısal verileri işlenmiştir. 


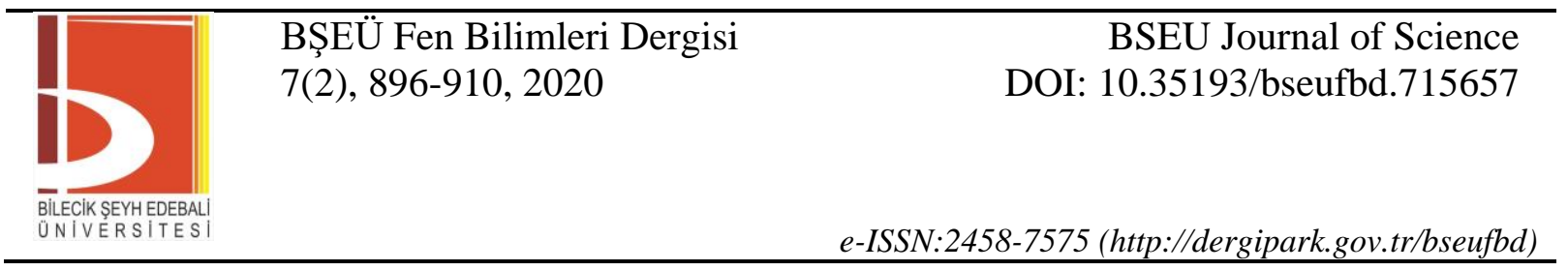

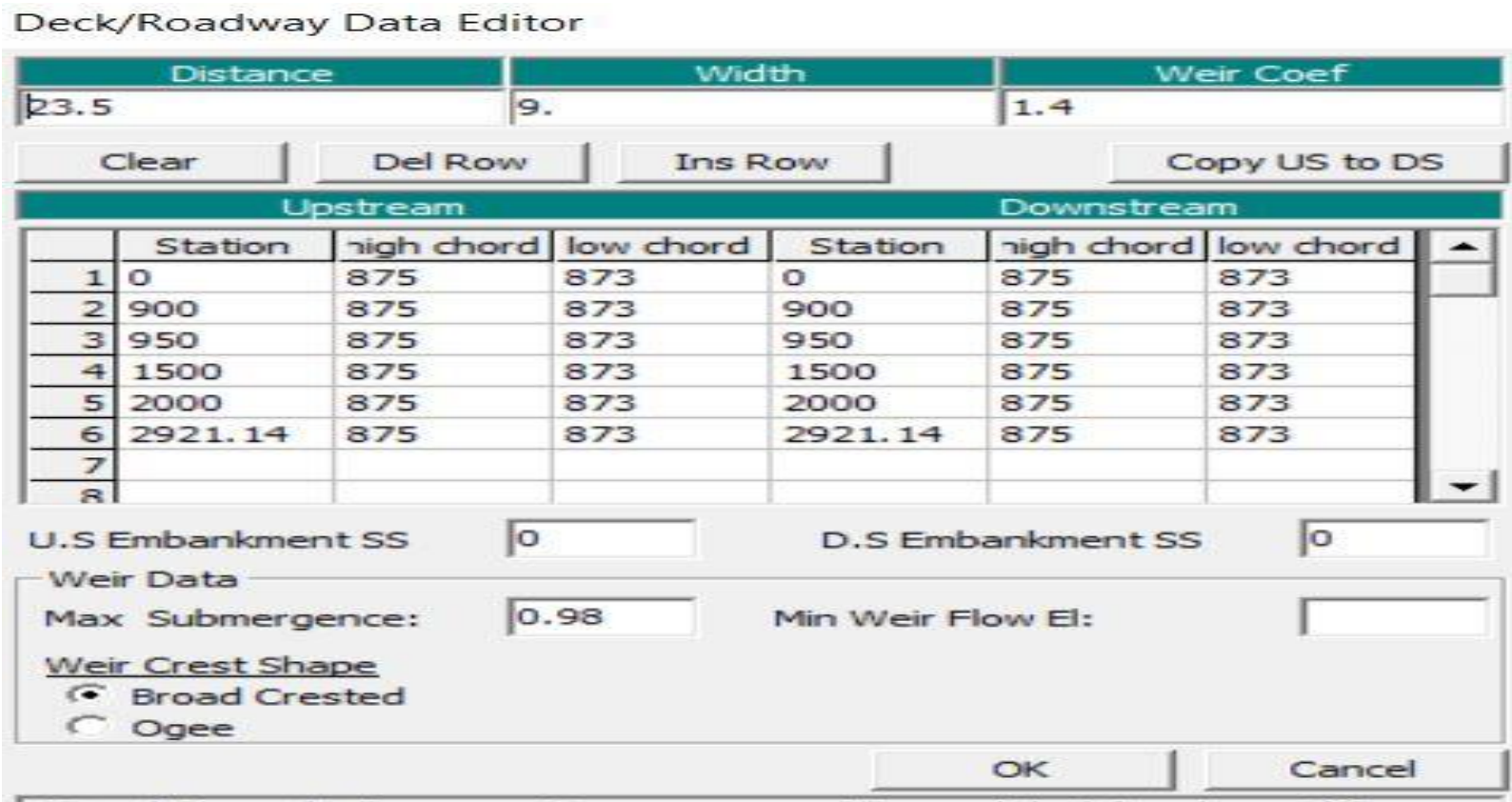

Enter distance between upstream cross section and deck/roadway. (m)

Şekil 5. HEC-RAS'ta köprüye ait verilerin girilmesi

Bir akarsu yatağındaki malzeme veya akarsuyun zemini nedeniyle suyun akış hızına etki edebilecek faktörleri ifade eden katsayıya Manning pürüzlülük katsayısı denir. Akarsuyun bulunduğu noktalarda akarsu zemininde bulunan ve suyun akış hızına etkisini ifade eden bir katsayıdır. Manning katsayısına etki ederek suyun hızının değişimine neden olan en önemli nedenler; suyun akış yatağı, aktığı yerdeki yamaçların büyüklüğü ve derenin akışşseklidir.

$$
\begin{aligned}
& \mathrm{Q}=\mathrm{V} * \mathrm{~A} \\
& \mathrm{Q}=\frac{\mathrm{A}}{\mathrm{n}} * R^{2 / 3} * S^{1 / 2} \\
& \mathrm{~V}=\frac{1}{n} * R^{2 / 3} * S^{1 / 2}
\end{aligned}
$$

akarsu debi ve suyun hızına ait formüllerin açılımı bu şekildedir.

$$
\begin{aligned}
& \text { Burada; } \\
& \text { Q= Debi, }\left(\mathrm{m}^{3} / \mathrm{s}\right), \\
& \text { V=Hız, }(\mathrm{m} / \mathrm{s}), \\
& \text { A = Alan, }\left(\mathrm{m}^{2}\right), \\
& \text { n =Manning pürüzlülük katsayısı, } \\
& \text { R=Hidrolik yarıçap, }(\mathrm{m}), \\
& \text { S=Ĕğim, (m/m)'i ifade etmektedir. }
\end{aligned}
$$


Su yüzü profillerini doğru olarak elde etmede " $n$ ” pürüzlülük katsayısı önemli rol oynamaktadır. Bu değer birçok faktöre bağlı olarak değişmektedir [13]. Çalışmada pürüzlülük değerini hesaplamak için Cowan yönteminden faydalanılmıştır. Yöntem 1956 yılında W.L. Cowan [14] tarafından geliştirilmiş ve 1989 yılında U.S.Geological Survey [15] tarafından modifiye edilmiştir. Yöntemde kullanılan denklem;

$\mathrm{n}=\mathrm{m} *\left(\mathrm{n}_{\mathrm{b}}+\mathrm{n}_{1}+\mathrm{n}_{2}+\mathrm{n}_{3}+\mathrm{n}_{4}\right)$

Burada;

m : Akarsu kanalının kıvrım derecesini ifade eder,

$\mathrm{n}_{\mathrm{b}}$ :Akarsu kanalının zemin özelliklerini ifade eder,

$\mathrm{n}_{1}$ : Akarsu kanalının yüzey düzensizliklerinin etkilerini ifadfe eder,

$\mathrm{n}_{2}$ : Akarsu kanalının enkesit şekli ve büyüklüğündeki değişimleri ifade eder,

$\mathrm{n}_{3}$ :Akarsu kanalındaki engellerin etkisini ifade eder,

$\mathrm{n}_{4}$ : Akım şartları ve bitki örtüsünü ifade eder.

Çalışmada incelenen akarsu kesimiiçin belirlenen katsayılar Tablo 1.’de verilmiştir.

Tablo 1. Akarsu pürüzlülük katsayısının belirlenmesi

\begin{tabular}{|c|c|c|c|c|}
\hline \multicolumn{2}{|c|}{ Kanal Şartları } & \multicolumn{2}{|c|}{ Değer Aralıkları } & Arazi Değerleri \\
\hline \multirow{4}{*}{ Zemin özellikleri } & Toprak & \multirow{4}{*}{$\mathrm{n}_{\mathrm{b}}$} & 0.020 & \multirow[t]{4}{*}{0.020} \\
\hline & Kaya & & 0.025 & \\
\hline & Kum & & 0.026 & \\
\hline & Çakıl & & 0.028 & \\
\hline \multirow{4}{*}{ Yüzey düzensizlikleri } & Pürüzsüz & \multirow{4}{*}{$\mathrm{n}_{1}$} & 0.000 & \multirow[t]{4}{*}{0.000} \\
\hline & Önemsiz & & 0.005 & \\
\hline & Orta & & 0.010 & \\
\hline & Şiddetli & & 0.020 & \\
\hline \multirow{3}{*}{ Enkesit şekli ve büyüklüğü } & Aşamalı & \multirow{3}{*}{$\mathrm{n}_{2}$} & 0.000 & \multirow[t]{3}{*}{0.000} \\
\hline & Arasıra Değişen & & 0.005 & \\
\hline & Sik Değişen & & $0.010-0.015$ & \\
\hline \multirow{4}{*}{ Engel etkileri } & İhmal edilebilir & \multirow{4}{*}{$\mathrm{n}_{3}$} & 0.000 & \multirow[t]{4}{*}{0.000} \\
\hline & Önemsiz & & $0.010-0.015$ & \\
\hline & Kayda değer & & $0.020-0.030$ & \\
\hline & Şiddetli & & $0.040-0.060$ & \\
\hline \multirow{4}{*}{ Bitki örtüsü } & Düşük & \multirow{4}{*}{$\mathrm{n}_{4}$} & $0.005-0.010$ & \multirow[t]{4}{*}{0.020} \\
\hline & Orta & & $0.010-0.025$ & \\
\hline & Yüksek & & $0.025-0.050$ & \\
\hline & Çok Yüksek & & $0.050-0.100$ & \\
\hline \multirow{3}{*}{ Kıvrım derecesi } & Önemsiz & \multirow{3}{*}{$\mathrm{m}$} & 1.000 & \multirow[t]{3}{*}{1.000} \\
\hline & Kayda değer & & 1.150 & \\
\hline & Şiddetli & & 1.300 & \\
\hline
\end{tabular}

Cowen yöntemine göre yapılan hesaplamalara göre pürüzlülük katsayısı 0.040 olarak belirlenmiştir. Çalışmada, akarsuyun sadece 10 km'lik kısmı incelendiğinden akarsu özelliklerinin fazla değişmediği düşünülerek burada tek pürüzlülük değeri kullanılmıştır. Hesaplanan Manning pürüzlülük katsayısı Şekil 6'da gösterildiği gibi her kesiti belirtilecek şekilde programa girilmiştir. 


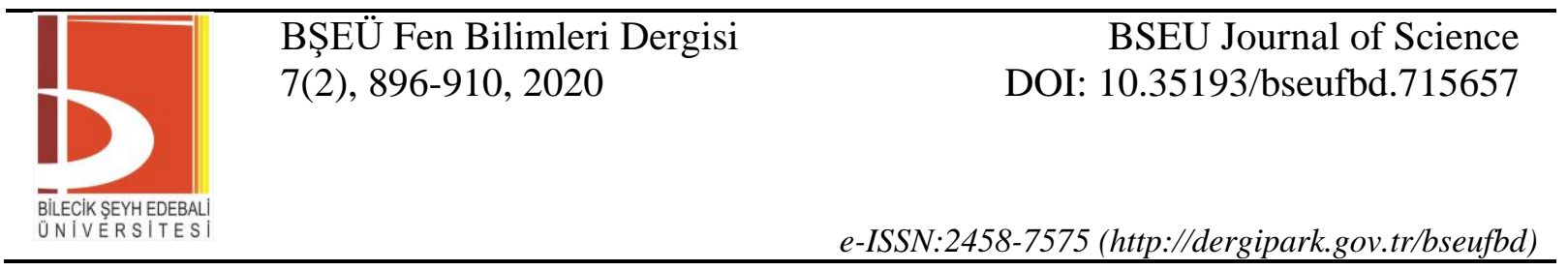

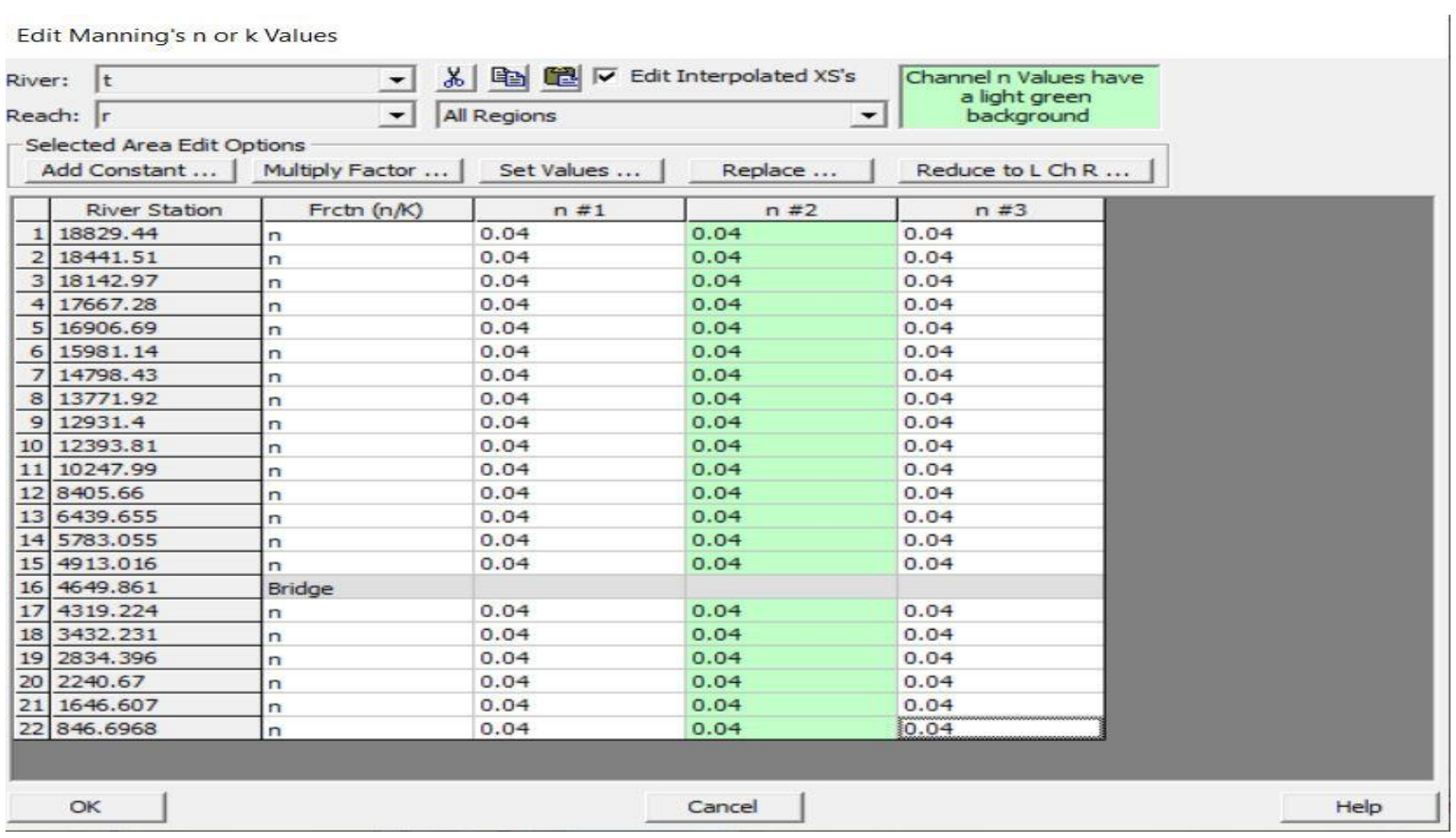

Şekil 6. En kesitlerdeki pürüzlülük katsayısı

DSİ 3. Bölge Müdürlüğünden alınmış olan akarsuya ait $\mathrm{Q}_{50}=139,58 \mathrm{~m}^{3} / \mathrm{s}, \mathrm{Q}_{100}=211,40 \mathrm{~m}^{3} / \mathrm{s}$ taşkın debileri Şekil 7'de görüldüğü gibi HEC-RAS programına işlenmiştir.

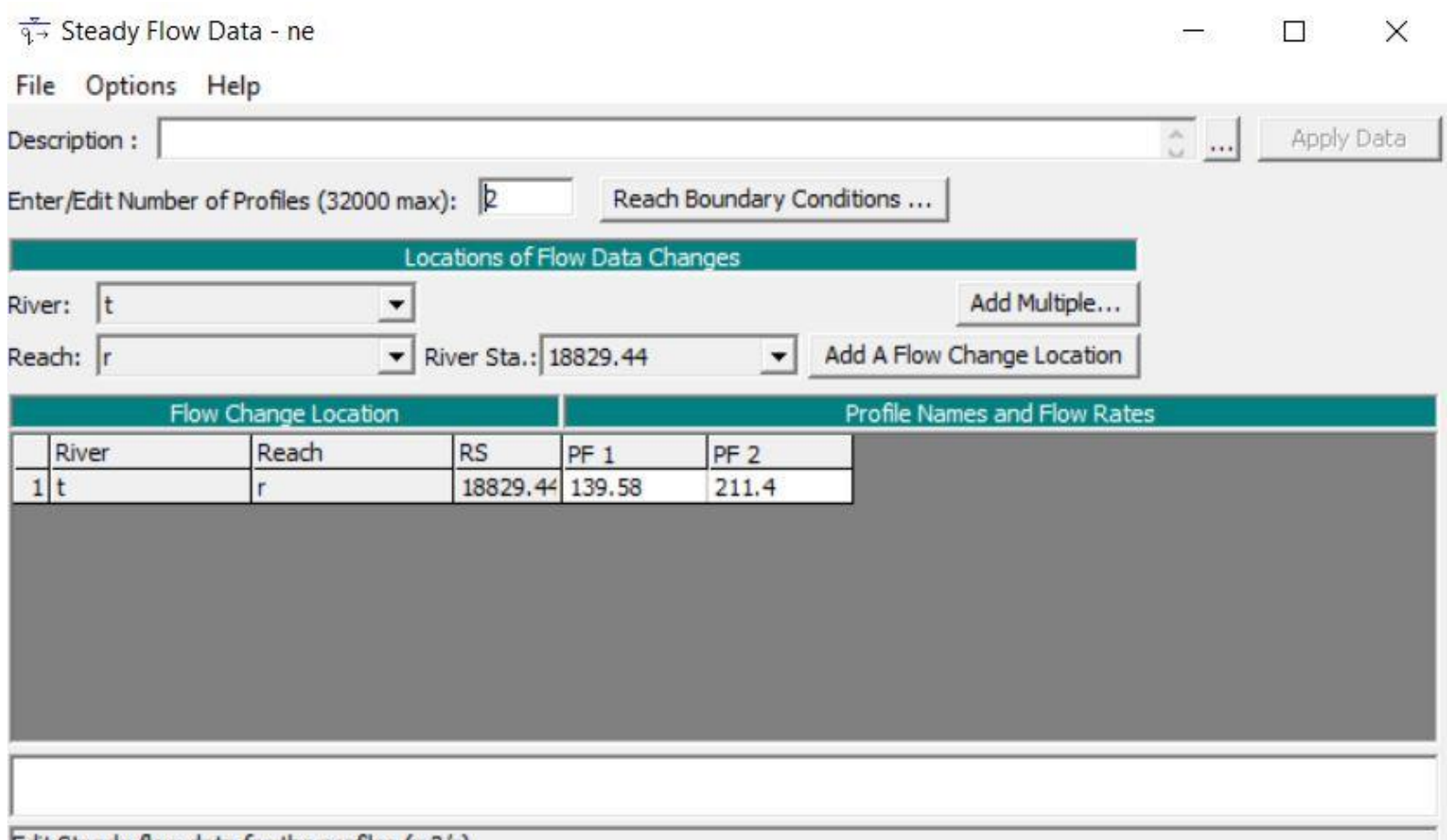

Edit Steadv flow data for the profiles $(\mathrm{m} 3 / \mathrm{s}$ )

Şekil 7. Taşkın debilerinin programa girilmesi 


\section{BULGULAR VE TARTIŞMA}

Fidanlık köprüsüne ait girilen veriler sonucunda $Q_{50}=139,58 \mathrm{~m}^{3} / \mathrm{s}, \quad Q_{100}=211,40 \mathrm{~m}^{3} / \mathrm{s}$ taşkın debilerindeki köprünün durumunu gösterir analiz HEC-RAS ile yapılmış ve sonuçlara ait çıktılar aşağıda görülmektedir (Şekil 8.).

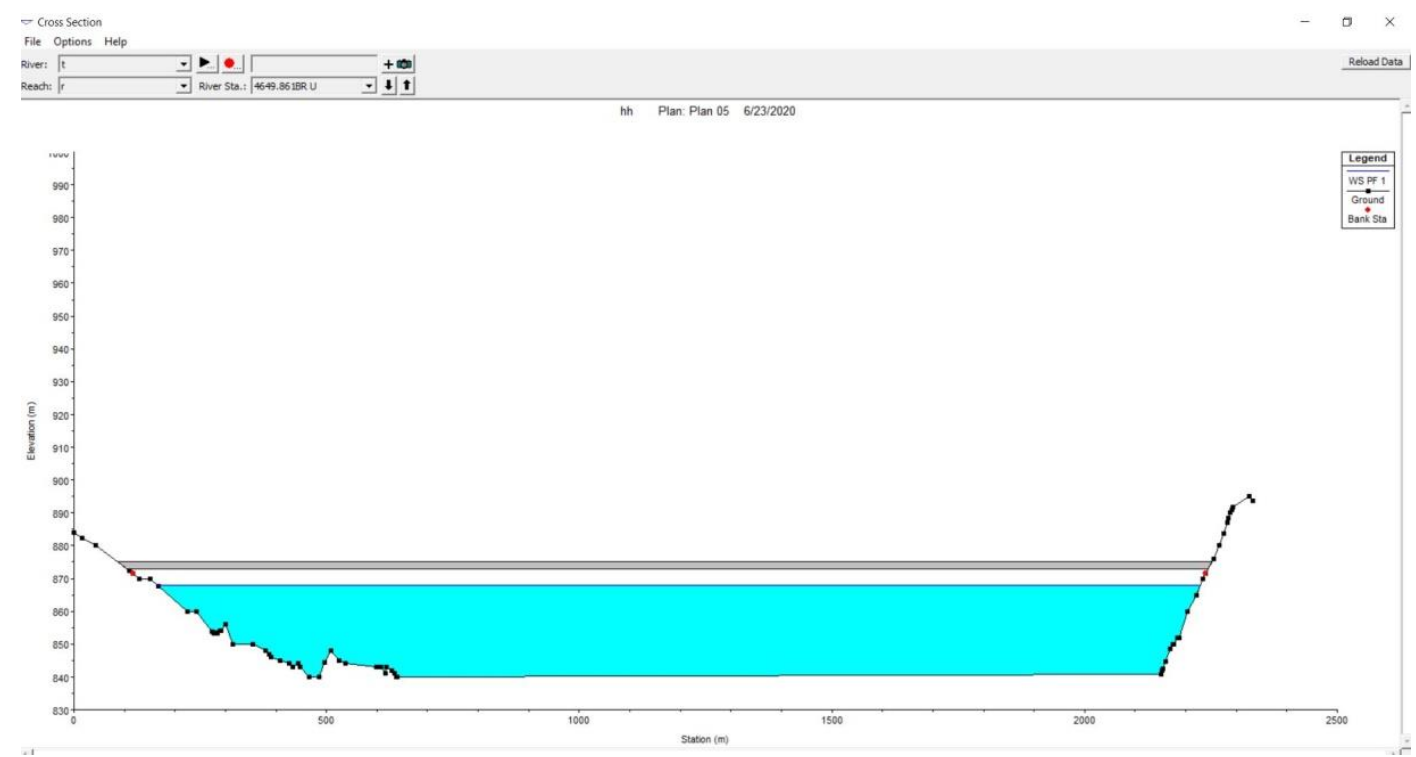

Şekil 8. $\mathrm{Q}_{50}=139,58 \mathrm{~m}^{3} / \mathrm{s}$ debisindeki köprü tabliyesinin durumu

Şekil 8'de köprünün tabliyesi ve ayak açılıl̆ğının $\mathrm{Q}_{50}=139,58 \mathrm{~m}^{3} / \mathrm{s}$ taşkın debisini karşılamakta oldukça güvenli olduğu ve köprü tasarımı ile ilgili herhangi bir sıkıntı bulunmadığı görülmektedir. Bu durumda $873 \mathrm{~m}$ kotundaki köprü tabliyesi alt kotuna 5 m mesafede olup 868 m kotunda su yüzü kotu olduğu görülmektedir.

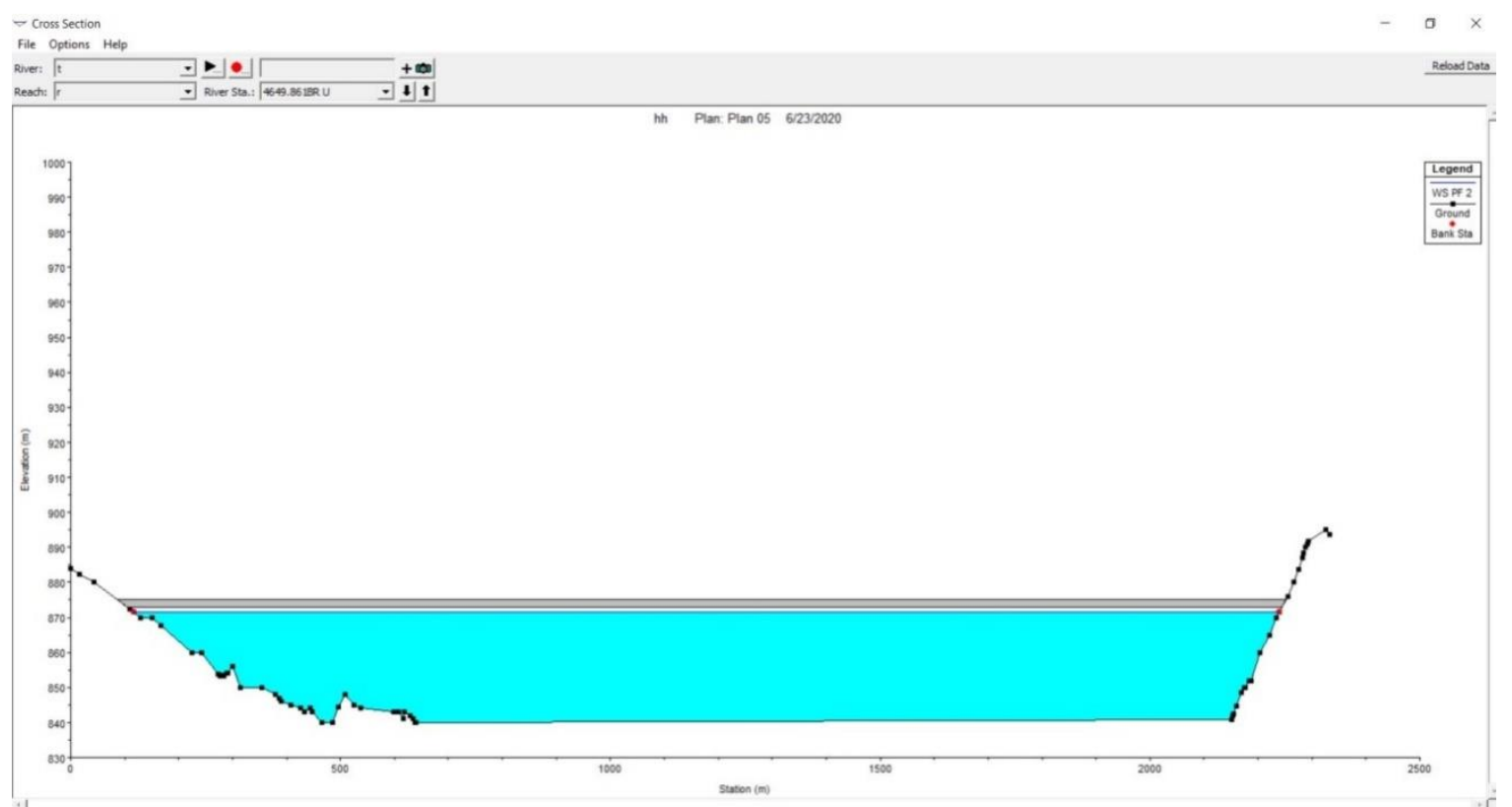

Şekil 9. $\mathrm{Q}_{100}=211,40 \mathrm{~m}^{3} / \mathrm{s}$ debisindeki köprü tabliyesinin durumu 


\begin{tabular}{|c|c|c|}
\hline & $\begin{array}{l}\text { BŞEÜ Fen Bilimleri Dergisi } \\
7(2), 896-910,2020\end{array}$ & $\begin{array}{r}\text { BSEU Journal of Science } \\
\text { DOI: } 10.35193 / \text { bseufbd. } 715657\end{array}$ \\
\hline & & 58-7575 (http://dergipark.gov.tr/bseufbd) \\
\hline
\end{tabular}

Şekil 9'da ise $\mathrm{Q}_{100}=211,40 \mathrm{~m}^{3} / \mathrm{s}$ taşkın debisinin karşılanmasında, köprü tabliyesi ve köprü açıklığının sınır değere çok yakın olmasına rağmen köprünün güvenli bölgede kaldığı görülmektedir. Bunda köprünün orta ayaksız olarak tasarlanmasının ve yapılan hava payı hesabının oldukça etkili olduğu görülmektedir. Şekil 9'a göre $873 \mathrm{~m}$ kotundaki köprü tabliyesi ile su yüzeyi arasında 1,5 m'lik kot fark1 olduğu görülmüștür. DSİ'nin planladığı gibi 100 yılda bir gelebilecek taşkında su yüzeyi kotu ile tabliye arasında 1,5 m'lik bir hava payı kaldığı hesaplarda doğrulanmıştır.

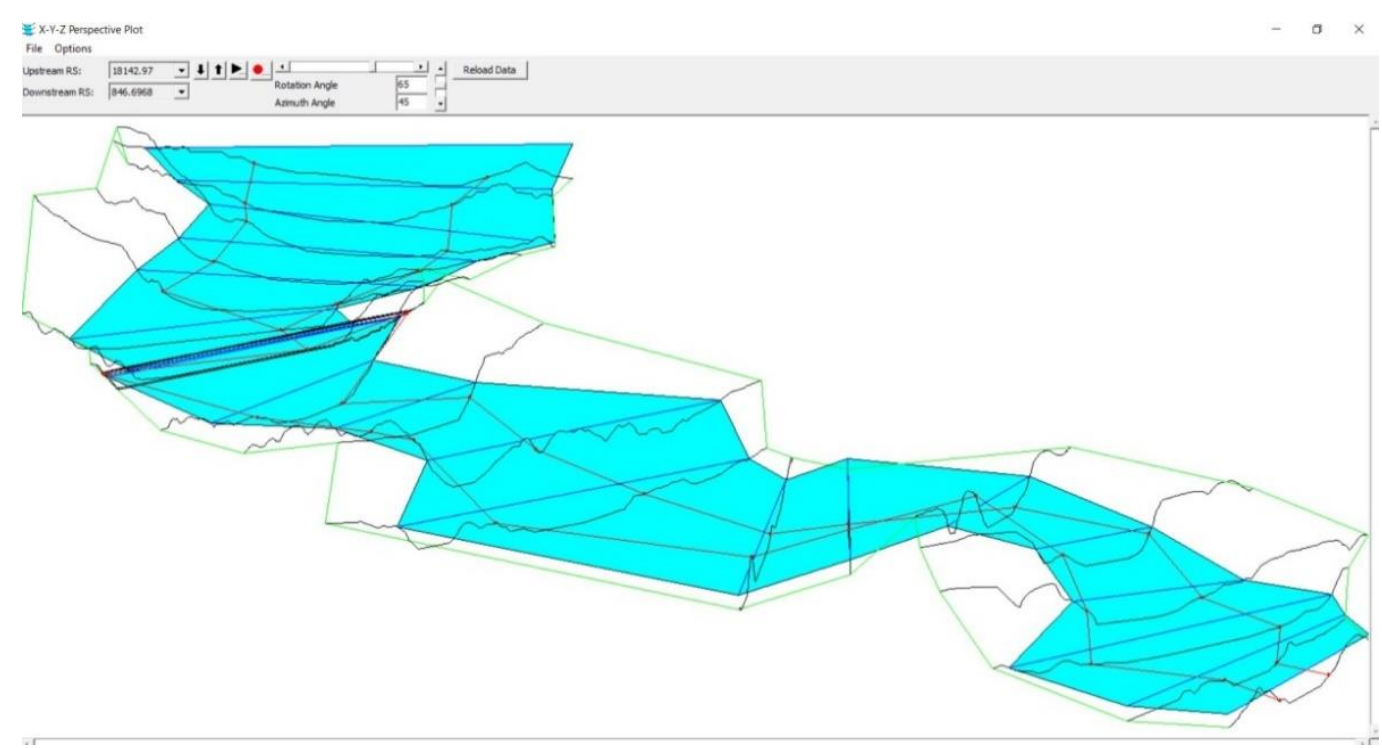

Şekil 10. $Q_{50}=139,58 \mathrm{~m}^{3} / \mathrm{s}$ debisindeki su yüzü profili

HEC-RAS bir boyutta ve düzensiz akımları modelleyen bir analiz programıdır. Köprüye ait geometrik verilerin, memba ve mansabına çizdiğimiz en kesitlerin $\mathrm{Q}_{50}$ ve $\mathrm{Q}_{100}$ taşkın debilerindeki durumu sonucu oluşan arazi topoğrafyasına ait akarsu su yüzü profilleri Şekil 10 ve Şekil 11'de 3X-Y-Z koordinatlarında perspektif olarak görülmektedir.

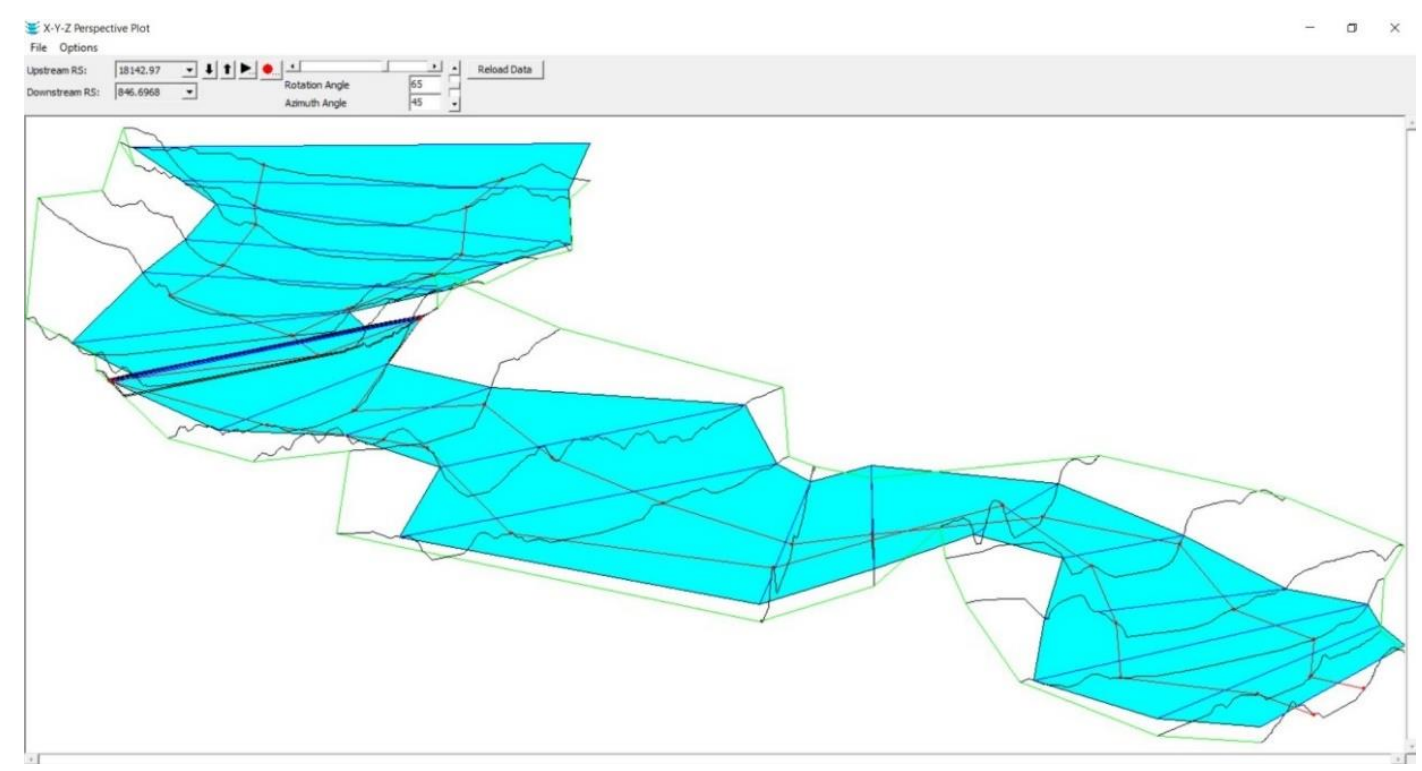

Şekil 11. $Q_{100}=211,40 \mathrm{~m}^{3} / \mathrm{s}$ debisindeki su yüzü profili 
Akarsu su yüzü profilli ve köprü en kesitindeki taşkın durumunu HEC-RAS sayesinde analiz ederek gerçek arazi geometrisinde köprü güvenliğini üç boyutlu olarak test edilmiştir. Ayrıca incelenen 10 km'lik akarsu kesiminde $\mathrm{Q}_{50}$ ve $\mathrm{Q}_{100}$ taşkın debilerinin oluşturacağı taşkın sınırları belirlenmiştir (Şekil $12 \mathrm{a}, \mathrm{b}$ ).
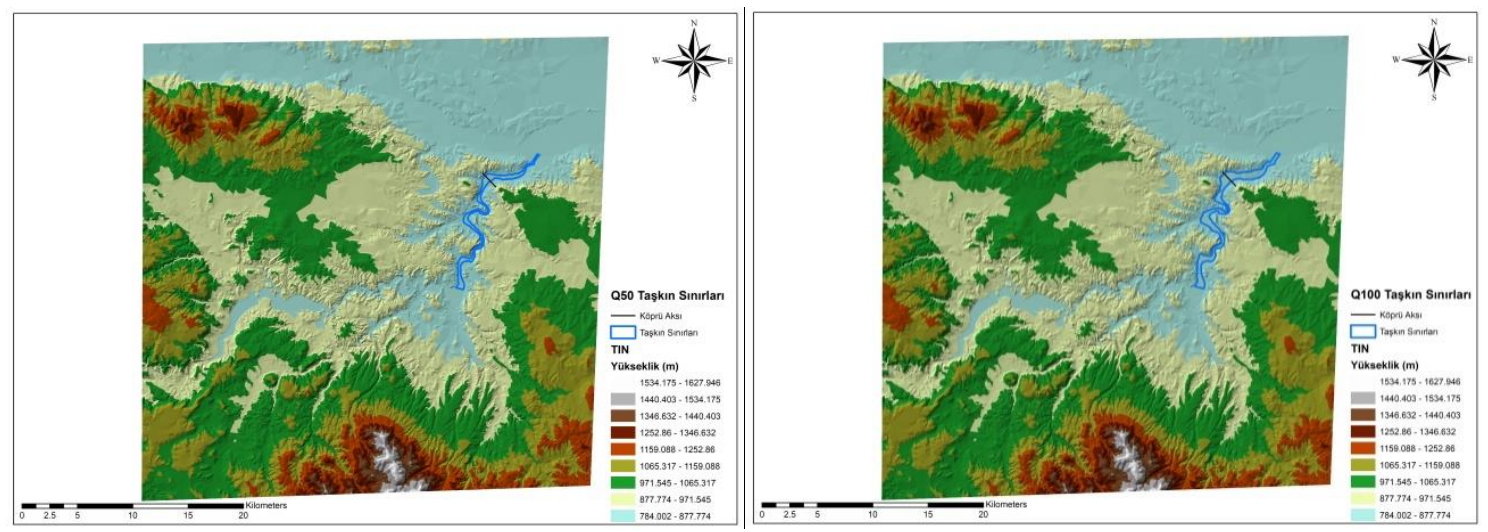

Şekil 12. a) $\mathrm{Q}_{50}$ taşkın debisine göre taşkın sınırları b) $\mathrm{Q}_{100}$ taşkın debisine göre taşkın sınırları

İncelenen akarsu güzergahı boyunca yerleşim alanı bulunmamaktadır. Ancak güzergâh boyunca akarsuyun sol ve sağ sahilinde birçok tarım arazisi mevcuttur. 50 yılda bir gelebilecek taşkın debisinde tarım arazilerinin çok az bir kısmı etkilenmektedir. Özellikle köprünün mansabındaki tarım arazileri etkilenmektedir. Ancak durum100 yılda bir gelebilecek taşkın debisinde değişmektedir. Bu durumda tarım arazilerinin yalnızca akarsuyun mansabında kalanlar eğil mansabındakilerde etkilenmektedir. Akarsuya komşu sol ve sağ sahilinde kalan tarım arazileri dışında kalan araziler etkilenmemektedir. Özellikle bölgede piknik ve mesire alanı olarak hizmet veren orman fidanlığı bölgesinin önemli bir kısmı $\mathrm{Q}_{100}$ taşkın debisinden daha büyük sular geldiğinde sular altında kalma riski yaşayabileceği görülmüştür. Köprünün yapıldığı aks kesit genişliği Q ${ }_{100}$ 'lük bir taşkın debisinde yalnızca 1,5 m hava payıyla kapasitesinin maksimumunu karşılayabilecek durumdadır. İncelenen akarsu güzergâhı boyunca imar izni şuanda bulunmamaktadır. Ancak ileriki yıllarda bölgede bulunan tarım arazilerine imar verilmesi durumunda taşkın riski altında olacağından sosyal ve ekonomik zararları göz önünde bulundurulmalıdır.

\section{SONUÇLAR}

Bu çalışmada Eskişehir Porsuk Çayı üzerine DSİ tarafından yapılmış olan Fidanlık köprüsünün hidrolik açıdan güvenliği ve analizi HEC-RAS programıla test edilerek ve yorumlanmıştır. Yapılan analiz sonucunda yapılacak köprülerin tasarım aşamasında hidrolik verilerin de dikkate alınmasının ne denli önemli olduğu ortaya ortaya konmuştur. Köprü tasarımının orta ayaksız olarak yapılması ve yapımı için seçilen konum düşünüldüğünde köprü tabliyesi ve açıklığının $\mathrm{Q}_{50}$ ve $\mathrm{Q}_{100}$ taşkın debilerini güvenle karşılayabildiği bilgisayar ortamında görülmüştür. Ancak bölgenin akarsu yatak genişliği ve düşük eğimli olması güzergâh boyunca bulunan tarım arazilerini gelebilecek taşkın büyüklüklerinin etkileyebileceği görülmüştür. Özellikle 100 yıllık bir periyotta oluşabilecek taşkın büyüklüğünde akarsuyun sağ ve sol sahiline komşu tarım arazilerini etkileyebileceği görülmüştür. Bölge için $\mathrm{Q}_{100}$ debisinden daha büyük bir debide bölge halkının sıklıkla tercih ettiği mesire alanının da etkilenebileceği öngörülmüştür. Eskişehir hızla büyüyen bir şehir olduğu göz önünde bulundurulduğunda ileriki yıllarda incelenen güzergah boyunca imarlaşma durumunda bölgenin taşkın riski altında olacağının unutulmaması gerekmektedir. Ancak köprünün üzerinde bulunduğu Porsuk çayının Porsuk barajıyla taşkın risklerine karşı korunduğu da bilinmektedir.

HEC-RAS programı ile hem köprünün bulunduğu yerdeki en kesitte taşkın anındaki tabliyenin durumunu, hem de akarsu yatağında taşkın debilerindeki arazinin durumu analiz edilmiştir. Köprüye 139,58 $\mathrm{m}^{3} / \mathrm{s}^{\prime}$ lik $\mathrm{Q}_{50}$ taşkın büyüklügü gelmesi durumunda köprü tabliyesi ve su yüzeyi kotu arasında $5 \mathrm{~m}$ olacağ görülmüştür. $\mathrm{Bu}$ durum $\mathrm{Q}_{50}$ taşkın büyüklügüünde köprünün güvenli bir şekilde stabilitesini koruyabileceğini ortaya koymuştur. Ancak 211,40 m³/s'lik Q Q 100 taşkın büyüklüğünde köprü tabliyesi ve su yüzeyi kotları arasında 
yalnızca $1,5 \mathrm{~m}$ fark olacağ görülmüşsür. Bu durum köprünün güvenle geçirebileceği suyun maksimum sınır şartlarını oluşturmaktadır. Bu durumda köprünün $211,40 \mathrm{~m}^{3} / \mathrm{s}$ debiden fazlası gelmesi durumunda statik olarak tehlikeli duruma geçebileceğini ortaya koymuştur.

$\mathrm{Bu}$ çalışmada bir akarsu üzerine planlanan bir köprünün akarsuyun hidrolik etkileri açısından analizlerinin yapılabileceğini ortaya konulmuştur. Böylelikle planlanmış işletmede veya işletmede olmayan tüm su yapılarının tasarımı bölgedeki taşkın debi büyüklüklerine göre analiz edilebileceği Eskişehir'de DSİ tarafından yapılmış olan Fidanlık köprüsü örneği üzerinden gösterilmiş̧ir. CBS ve HEC-RAS gibi yazılımların köprü güvenliği çalışmalarında gelecekte de kullanılmaya devam edeceği düşünülmektedir. Mevcut bir akarsu üzerinde bulunan köprünün gelebilecek taşkın büyüklüklerinde su yükselmesi, köprü tabliyesini ne kadar tehdit ettiği, su yükseklikleri belirlenmesi hesaplarında CBS ve HEC-RAS gibi yazılımların günümüzde olduğu gibi gelecekte de kullanılmaya devam edileceği düşünülmektedir. Bu çalışmayla literatürde taşkın ve köprü güvenliği konularında yapılan çalışmalara katkı sağlayacağı düşünülmektedir. Özellikle son yıllarda sıklıkla can ve mal kaybına yol açan taşkın felaketlerinin su yapıları üzerindeki hidrolik etkilerinin belirlenerek köprü tasarım kriterlerinin belirlenmesi açısından günümüzde ve gelecekte yeni fikir ve çalışmalarla bu konudaki araştırmaların devam edeceği düşünülmektedir.

\section{KAYNAKLAR}

[1] Darama Y. (2013). Taşkın Tehlike Haritaları Çalışmaları, DSI Hizmet İçi Eğitim Semineri, Ankara.

[2] DSİ, (2011). Sargın A. H., Coğrafi Bilgi Sistemleri İle Taşkın Riski Ön Değerlendirmesi, Ankara.

[3] Bülbül, M. M., \&Demirel, E.(2012). Taşkın Sırasındaki Köprü Ayaklarındaki Kabarmaların Analizi: Ova Çayı Örneği. İnşaat Mühendisliği'nde 100. Yll Teknik Kongresi, 22-24 Kasım, Yıldız Teknik Üniversitesi, İstanbul.

[4] Doğu,A., \&Yıldız, O. (2019). Kırıkkale Çoruzözü Deresi’nde Bir Boyutlu Taşkın Modellemesi. K.Ü. Uluslararası Mühendislik Araştırma ve Gelişstirme Dergisi.11. Cilt (2), 748-758.

[5] Efe,H., \&Önen, F. (2015). Batman Çayı'nın Taşkın Analizinin HEC-RAS Programıyla Yapılması. D.Ü. Mühendislik Dergisi.6. Cilt (2), 83-92.

[6] Ercan,B., Yağcı, E. A., \&Ünsal, M. (2019). KahramanmaraşDomuz (Boğaz) DeresiKuşaklamaKanalının HEC-RAS Modeli.AÇÜ.DoğalAfetlerAraştırmaveUygulamaMerkezi, DoğalAfetlerveÇevreDergisi.5. Cilt (1), 58-64.

[7] Karaca C.,Birdal C,A., \&Türk, T. (2016). Taşkın Risk Alanlarının Coğrafi Bilgi Sistemleri ile İncelenmesi. 6. Uzaktan Algilama CBS Sempozyumu (UZAL-CBS), 5-7 Ekim, Adana, 118-125.

[8] Özdemir, H.(2007). Taşkınların Haritalanmasında Hec-GeoRAS ve HEC-RAS'ın Kullanımı: Havran Çayı Örneği (Balıkesir).Ulusal Coğrafi Bilgi Sistemleri Kongresi, 30 Ekim-2Kasım, Trabzon.

[9] Seçilir, S. (2005). Akarsular Üzerindeki Farkl Kesitli Köprü Yapılarının Su Yüzü Profillerine Etkisi. Erciyes Üniversitesi, Fen Bilimleri Enstitüsü, İnşaat Mühendisliği Ana Bilim Dalı, Yüksek Lisans Tezi, Kayseri.

[10] Taş, E., İçağa, Y., \&Zorluer, E. (2016). Taşkın Yayılım Haritalarının Oluşturulması veTaşkın Zarar Analizi: Akarçay Afyon Alt Havzası Örneği. AKÜ. Fen veMühendislikBilimleriDergisi.16. Cilt (3), 711721.

[11] Üyüklüoğlu, M.,Ünal, B.,\&Turan, B.(2015). HEC-RAS Paket Programı İle Manavgat İlçesi Ilıca Deresi Taşkın Bölgesinin Modellenmesi.4. Su Yapıları Seтроzуити, 19-20Kasım, Antalya. 
[12] USACE. (2009). HEC-GeoRAS, GIS Tools for support of HEC-RAS using ArcGIS, User's Manual, Version 4.2.

[13] Oğraş, S., \&Önen, F. (2019). Dicle Nehri'nin taşkın analizinin HEC-RAS programı ile yapılması. DÜMF Mühendislik Dergisi 10(3), 1087-1098.

[14] Cowan, W. L. (1956). Estimating hydraulic roughness coefficients. Agric. Eng., 37(7), 473-475.

[15] Arcement,V. R., \& Schneider, G. J. (1989). Guide for Selecting Manning's Roughness Coefficients for Natural Channels and Flood Plains. U.S. Geological Survey Water Supply Paper, 2339. 